\title{
POTENSI PENAMBAHAN Azolla sp. DALAM FORMULASI PAKAN IKAN LELE (Clarias sp.) TERHADAP NILAI KECERNAAN PROTEIN DAN KECERNAAN ENERGI MENGGUNAKAN TEKNIK PEMBEDAHAN
}

\section{Potential Addition of Azolla sp. in Catfish (Clarias sp.) Feed Formulations Against Protein Digestibility Value and Digestibility of Energy Using Surgical Technique}

\author{
Ratna Eka Wardani ${ }^{1 *}$, Prayogo,S.Pi., MP² dan Agustono, Ir., M.Kes² \\ ${ }^{1}$ Program Studi Budidaya Perairan, Fakultas Perikanan dan Kelautan, Universitas Airlangga, Surabaya \\ ${ }^{2}$ Departemen Manajemen Kesehatan Ikan dan Budidaya Perairan, Fakultas Perikanan dan Kelautan, Universitas \\ Airlangga, Surabaya \\ *ratnawardani94@gmail.com
}

\begin{abstract}
Abstrak
Ikan lele merupakan salah satu jenis ikan yang sangat potensial untuk dikembangkan sebagai ikan konsumsi. Permintaan pasar ikan lele di Indonesia semakin meningkat sehingga produksi yang dibutuhkan semakin tinggi, untuk itu dengan penambahan tepung azolla sebagai salah satu campuran bahan formulasi pakan ikan lele dibutuhkan untuk memacu pertumbuhan atau meningkatkan produktivitas ikan lele. Azolla sp. merupakan tanaman paku air yang selama ini dianggap sebagai gulma oleh para petani sehingga tidak dimanfaatkan, namun Azolla sp. memiliki kandungan protein yang cukup tinggi berkisar antara 24-30\%sehingga dengan penambahan tanaman Azolla dapat menurunkan biaya produksi serta mempercepat pertumbuhan ikan lele. Penelitian ini bertujuan untuk mengetahui pengaruh penambahan tanaman Azolla sp..pada formulasi pakan terhadap nilai kecernaan protein dan kecernaan energi ikan lele menggunakan teknik pembedahan. Metode penelitian ini menggunakan Rancangan Acak Lengkap (RAL) dan perlakuan yang dilakukan dalam penelitian ini menggunakan perbedaan jumlah persen Azolla sp. yaitu menggunakan P0 sebagai kontrol dengan penambahan Azolla sp. 0\%, P1 penambahan Azolla sp. 5\%, P2 penambahan Azolla sp. 10\%, P3 penambahan Azolla sp. 15\%, P4 penambahan Azolla sp. 20\%. Kemudian dilakukan ulangan sebanyak 4 kali. Hasil Penelitian ini menggunakan penambahan Azolla sp. terhadap nilai kecernaan protein berbeda nyata $(\mathrm{P}<0,05)$ sedangkan untuk penambahan Azolla sp. terhadap nilai kecernaan energi tidak berbeda nyata $(\mathrm{P}>0,05)$. Untuk kadar kecernaan protein tertinggi pada perlakuan P3 dengan penambahan Azolla sp. 15\% dan kadar kecernaan energi tertinggi pada perlakuan P2 dengan penambahan Azolla sp. 10\%.
\end{abstract}

Kata Kunci: Azolla sp., Ikan Lele, Pakan Formulasi, Kecernaan Protein, Kecernaan Energi

\begin{abstract}
Catfish is one type of fish that very potential to be developed as a food fish. Market demand for catfish in Indonesia has increased so that the required production is higher, for that with the addition of Azolla flour as a mixture of catfish feed formulations are needed to stimulate the growth or increase the productivity of catfish. Azolla sp. is a water spikes plant that had been considered a weed by farmers that is not utilized, but Azolla sp. has a fairly high protein content ranging between $24-30 \%$ so the addition of Azolla sp. can reduce the costs production and accelerate the growth of catfish. This research aimed to know the effect of Azolla flour to the formulation of feed materials on the protein digestibility and energy digestibility of catfish using surgical technique. This research method uses design of completely randomized (CRD) and the treatment that performed in this study using a different amount of percent Azolla sp. P0 is used as a control with the addition of Azolla sp. $0 \%, \mathrm{P} 1$ addition of Azolla sp. 5\%, P2 addition of Azolla sp. 10\%, P3 addition of Azolla sp. 15\%, P4 addition of Azolla sp. 20\%. Then do repea;pt 4 times. The results of this study using the addition of Azolla sp. to the protein digestibility values were significantly different $(\mathrm{P}<0.05)$ while for the addition of Azolla sp. to the energy digestibility values were not significantly different $(\mathrm{P}>0.05)$. For the highest levels of protein digestibility in $\mathrm{P} 3$ treatment with the addition of Azolla sp.15\% and the highest levels of energy digestibility in P2 treatment with the addition of $10 \%$.
\end{abstract}

Keywords: Azolla sp., Catfish, Feed Formulation, Protein Digestibility, Energy Digestibility 


\section{PENDAHULUAN}

Ikan lele (Clarias sp.) merupakan salah satu jenis ikan yang sangat potensial untuk dikembangkan sebagai ikan konsumsi. Ikan ini mempunyai beberapa keunggulan diantaranya, relatif tahan terhadap penyakit, oksigen terlarut yang rendah, memiliki pertumbuhan yang cepat dan sangat responsif terhadap pakan yang diberikan (Suyanto 2005). Produksi lele di Indonesia dari tahun ke tahun mengalami peningkatan. Pada tahun 2011 produksi ikan lele di Jawa Timur mencapai 715,865 ton, sedangkan pada tahun 2012 mencapai 927,974ton (DKP, 2003).

Pakan merupakan salah satu komponen terpenting dalam proses budidaya karena berperan dalam menunjang partumbuhan dan kelangsungan hidup ikan budidaya. Pakan pada suatu proses budidaya menghabiskan sekitar $60-70 \%$ biaya produksi yang dikeluarkan (Afrianto, 2005). Ketersediaan pakan yang memenuhi syarat gizi, mudah dicerna dan disukai ikan, tersedia dalam jumlah yang cukup, tepat waktu, serta berkesinambungan merupakan faktor yang sangat penting dalam budidaya ikan.

Harga pakan komersial sekarang ini semakin mahal sehingga dapat menambah biaya produksi. Salah satu cara untuk mengurangi biaya pakan adalah dengan menggunakan pakan alternatif, salah satunya dengan menggunakan Azolla sp. yang berasal alam. Azolla sp. merupakan tanaman yang biasa hidup di atas permukaan air. Azolla sp. dapat ditemukan pada semua persawahan di Indonesia. Petani masih banyak yang menganggap tanaman Azolla sp. gulma. (Cecep Hidayat dkk., 2011). Tanaman Azolla sp. memiliki kandungan protein yang cukup tinggi yaitu $28,12 \%$ berat kering, $10-15 \%$ mineral, dan $7-10 \%$ asam amino (Handajani, 2006). Karbohidrat dan lemak dari Azolla sp.juga rendah sehingga sangat baik sebagai pakan (Nurul dkk., 2013).Kecernaan suatu bahan pakan merupakan pencerminan dari tinggi rendahnya nilai manfaat dari bahan pakan tersebut (Ranjhan, 1997). Pengukuran kecernaan merupakan suatu usaha dalam menentukan jumlah zat pakan yang diserap dalam saluran pencernaan. Jumlah yang tertinggal dalam tubuh hewan atau jumlah dari zat pakan yang dicerna adalah selisih zat pakan yang terkandung dalam pakan yang dikonsumsi dan zat pakan dalam usus (Utama dkk, 2006).

Oleh karena itu saya mengambil penelitian mengenai pengaruh penambahan Azolla terhadap formulasi pakan ikan lele untuk meningkatkan nilai kecernaan protein dan kecernaan energi yang dapat memicu pertumbuhan ikan lele lebih cepat sehingga dapat memenuhi kebutuhan permintaan di pasar dan juga dapat mengurangi biaya pakan karena Azolla memiliki harga yang murah.

\section{METODOLOGI}

\section{Waktu dan Tempat}

Penelitian ini dilaksanakan di Laboratorium Fakultas Perikanan dan Kelautan Universitas Airlangga Surabaya pada bulan Juli sampai bulan Agustus 2016. Analisis proksimat bahan baku pakan, analaisis prokimat pakan dan analisis proksimat kecernaan pada feses dilakukan di Laboratorium Pakan Fakultas Kedokteran Hewan Universitas Airlangga Surabaya.

\section{Materi Penelitian}

Peralatan Penelitian

Alat yang digunakan dalam penelitian adalah akuarium sebanyak 20 buah

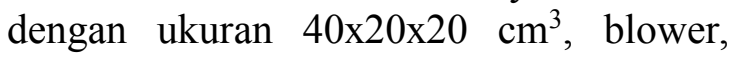
aerasi, selang aerasi, batu aerasi, termometer, nampan, gunting bedah, penggilingan, alat pencetak pelet, loyang, timbangan digital, $\mathrm{pH}$ paper, $\mathrm{DO}$ meter, ammonia test-kit, seser, plastik, sendok, alat sipon dan saringan.

\section{Bahan Penelitian}

Bahan penelitian yang akan digunakan dalam penelitian ini adalah ikan lele (Clarias sp.) dengan ukuran 8-9. Ikan ini berasal dari Pasar Ikan Gunung Sari. Ikan lele yang digunakan sebanyak 200 ekor. 
Media pemeliharaan yang digunakan dalam penelitian ini adalah air tawar sebanyak 10 liter. Air media penelitian berasal dari sumber air, agar tetap optimum setiap dua hari sekali dilakukan pergantian air sebanyak $50 \%$ dari total volume. Setiap satu minggu sekali dilakukan pergantian air secara keseluruhan. Bahan pakan yang digunakan dalam penelitian ini adalah tepung azolla, tepung ikan, tepung kedelai, tepung jagung, dedak, tepung tapioka dan vitamin mix.

\section{Metode Penelitian}

Penelitian ini mengunakan metode eksperimental dengan lima perlakuan dan 4 ulangan. Penelitian ini ingin mengetahui potensi penambahan azola dengan perlakuan $\mathrm{P}_{0}, \mathrm{P}_{1}, \mathrm{P}_{2}, \mathrm{P}_{3}$, dan $\mathrm{P}_{4}$ terhadap kecernaan serat kasar dan bahan ekstrak tanpa nitrogen ikan lele. Rancangan percobaan yang digunakan adalah Rancangan Acak Lengkap (RAL).

\section{Prosedur Kerja}

Aklimatisasi ikan lele terlebih dahulu selama satu hari. Menurut Rosadi (2012) aklimatisasi benih ikan adalah waktu yang diperlukan oleh ikan untuk beradaptasi dengan lingkungannya yang baru. Kemudian dipuasakan selama satu hari untuk menghilangkan pengaruh pakan yang diberikan sebelumnya.

Ikan yang digunakan dalam penelitian ini adalah ikan lele (Clarias sp.) ukuran 8-9 yang sehat dan tidak terserang penyakit. Benih ikan ditebar saat suhu sedang rendah, yaitu pagi atau sore hari (Cahyono, 2000). Aklimatisasi ikan lele terlebih dahulu selama satu hari. Menurut Rosadi (2012) aklimatisasi benih ikan adalah waktu yang diperlukan oleh ikan untuk beradaptasi dengan lingkungannya yang baru. Kantung plastik dibiarkan terapung diatas permukaan air selama 5-10 menit, kemudian tambahkan air media sedikit ke dalam kantong plastik sampai kondisi air yang ada didalamnya hampir sama dengan kondisi air yang ada di bak. Benih ikan lele yang digunakan sebanyak
10 ekor setiap akuarium (1/1L). Bahan pakan yang akan digunakan untuk pakan buatan, dianalisis proksimat untuk mengetahui kandungan nutrisinya. Bahan pakan yang telah digiling dilakukan pengayakan terlebih dahulu sehingga menghasilkan bahan yang halus sebelum dicampur. Bahan pakan yang telah diayak kemudian ditimbang sesuai dengan formulasi yang dikehendaki. Setelah dilakukan pengayakan dan penimbangan dilakukan pencampuran secara homogen. Bahan pakan yang telah tercampur merata dimasukkan ke dalam loyang kemudian diangkat dan dicetak dengan menggunakan mesin pelet. Pelet yang sudah setengah jadi kemudian dikeringkan dengan suhu $60^{\circ} \mathrm{C}$ selama 24 jam dengan menggunakan oven, setelah di oven selama 24 jam pelet siap digunakan. Pakan yang sudah jadi kemudian dianalisis proksimat untuk mengetahui kandungan nutrisi pakan untuk melihat kandungan protein, lemak, BETN, serat kasar dan abu.

\section{Analisis Data}

Data kecernaan protein dan kecernaan energi ikan lele dianalisa menggunakan Analysis of Varian (ANOVA). Apabila hasil analisa statistik menunjukkan pengaruh yang berbeda nyata atau berbeda sangat nyata, maka dilanjutkan dengan Uji Jarak Berganda Duncan untuk membandingkan pengaruh perlakuan (Kusriningrum, 2008).

\section{HASIL DAN PEMBAHASAN Kecernaan Protein}

Hasil perhitungan yang dilakukan pada feses ikan lele (Clarias sp.) setelah dilakukan pemeliharaan selama 28 hari dan dilakukan uji kecernaan di Laboratorium Fakultas Kedokteran Hewan Universitas Airlangga Surabaya didapatkan hasil kisaran kecernaan protein pada feses ikan lele dengan rata-rata 95,408\% $97,4150 \%$. Data rata-rata kecernaan protein dapat dilihat pada tabel 1.

Hasil perhitungan Analysis of Variant (ANOVA) menunjukkan adanya perbedaan yang nyata $(\mathrm{P}<0,05)$ pada 
kecernaan protein ikan lele. Berdasarkan hasil Uji Jarak Berganda Duncan (Duncan's Multiple Range Test) menunjukan antara perlakuan P0 dengan penambahan azolla sebanyak 0\% sebagai kontrol berbeda nyata dengan perlakuan P1 (5\%), P2 (10\%), P3 (15\%), P4 (20\%). Hasil Uji Jarak Berganda Duncan (Duncan's Multiple Range Test) menunjukkan hasil tertinggi kecernaan protein terdapat pada perlakuan penambahan azolla pada perlakuan P3 dengan penambahan azolla(15\%) dan kecernaan protein terendah terdapat pada perlakuan P0 dengan penambahan azolla (0\%).
Berdasarkan hasil analisa statistik kecernaan protein didapatkan hasil ratarata pada berkisar antara 95,408\% 97,4150\%. Kemudian dilakukan uji ANOVA dan didapatkan hasil $(\mathrm{P}<0,05)$ yang berarti bahwa terdapat perbedaan yang nyata pada perlakuan kecernaan protein tersebut. Selanjutnya dilakukan uji Duncan untuk mengetahui perbedaan dari setiap perlakuan Uji Duncan dilakukan untuk memberikan notasi kepada setiap perlakuan agar mengetahui perbedaan pada perlakuan.

Tabel 1. Rata-rata Nilai Kecernaan Protein Ikan Lele

\begin{tabular}{lcc}
\hline Perlakuan & $\begin{array}{c}\text { Nilai Kecernaan } \\
\text { Protein } \\
(\%) \pm \text { SD }\end{array}$ & $\begin{array}{c}\text { Transformasi }(\sqrt{ }) \pm \\
\text { SD }\end{array}$ \\
\hline P0 (0\% Azolla) & $95,408^{\mathrm{a}} \pm 0,737$ & $9,768 \pm 0,377$ \\
P1 (5\% Azolla) & $97,278^{\mathrm{b}} \pm 0,715$ & $9,863 \pm 0,362$ \\
P2 (10\% Azolla) & $97,405^{\mathrm{b}} \pm 1,274$ & $9,869 \pm 0,646$ \\
P3 (15\% Azolla) & $97,415^{\mathrm{b}} \pm 0,641$ & $9,870 \pm 0,325$ \\
P4 (20\% Azolla) & $97,098^{\mathrm{b}} \pm 1,144$ & $9,854 \pm 0,580$ \\
\hline
\end{tabular}

Keterangan: $\mathrm{SD}=$ Standar Deviasi

\section{Kecernaan Energi}

Berdasarkan hasil analisa statistik kecernaan energi didapatkan hasil rata-rata pada setiap perlakuan, Kemudian dilakukan uji ANOVA dan didapatkan hasil (P > $0,05)$ yang berarti bahwa tidak terdapat perbedaan yang nyata pada perlakuan kecernaan energi tersebut. Dengan demikian tidak perlu melakukan uji Duncan untuk memberi notasi karena tidak terdapat perbedaan pada setiap perlakuan pada kecernaan energi.Data rata-rata nilai kecernaan energi ikan lele dapat dilihat pada Tabel 2.

\section{Kualitas Air}

Data nilai kisaran parameter kualitas air pada pemeliharaan ikan lele selama 28 hari dapat dilihat pada Tabel 3 .

Tabel 2. Rata-rata Nilai Kecernaan Energi Ikan Lele

\begin{tabular}{ccc}
\hline Perlakuan & $\begin{array}{c}\text { Nilai Kecernaan Energi } \\
(\%) \pm \text { SD }\end{array}$ & Transformasi $(\sqrt{ }) \pm$ SD \\
\hline P0 (0\% Azolla) & $96,888 \pm 0,345$ & $9,843 \pm 0,175$ \\
P1 (5\% Azolla) & $96.932 \pm 1,038$ & $9,845 \pm 0,529$ \\
P2 (10\% Azolla) & $97,670 \pm 0,835$ & $9,882 \pm 0,422$ \\
P3 (15\% Azolla) & $96,878 \pm 0,873$ & $9,843 \pm 0,443$ \\
P4 (20\% Azolla) & $96,375 \pm 0,889$ & $9,817 \pm 0,453$ \\
\hline
\end{tabular}

Keterangan: $\mathrm{SD}=$ Standar Deviasi 
Tabel 3. Nilai Kisaran Parameter Kualitas Air pada Pemeliharaan Ikan lele

\begin{tabular}{cccc}
\hline No. & Parameter & Satuan & Kisaran \\
\hline & & ${ }^{\circ} \mathrm{C}$ & $28-30$ \\
1. & Suhu & $\mathrm{mg} / 1$ & 4 \\
2. & Oksigen terlarut (DO) & - & $7,5-8,0$ \\
3. & $\mathrm{pH}$ & &
\end{tabular}

\section{Pembahasan}

\section{Kecernaan Protein}

Protein merupakan senyawa yang memegang peranan penting dalam struktur dan fungsi tubuh, seperti pertumbuhan dan reproduksi. Oleh karena itu, protein dalam pakan ikan mutlak diperlukan (Murtidjo, 2001). Kecernaan merupakan suatu bagian dari pakan yang dikonsumsi dan tidak dikeluarkan menjadi feses (Affandi, et al., 1992). Kecernaan protein merupakan jumlah protein pakan yang diserap oleh tubuh ikan dan tidak dikeluarkan melalui feses.

Berdasarkan data nilai rata-rata kecernaan protein pada Tabel 1, pada perhitungan Analysis of Varian (ANOVA) menunjukkan bahwa pakan perlakuan ikan lele yang diberikan berbeda nyata karena $(\mathrm{p}<0,05)$. kemudian dilanjutkan dengan uji jarak berganda Duncan (Duncan's Multiple Range Test) diketahui bahwa ke lima perlakuan pakan terdapat perbedaan pada nilai kecernaan.

Nilai kecernaan protein tertinggi diperoleh pada perlakuan P3 (15\% Azolla) dengan nilai rata- rata $97,415 \%$ dan nilai kecernaan terendah terdapat pada perlakuan P0 ( $0 \%$ Azolla) dengan nilai ratarata $95,408 \%$. Hal ini sesuai dengan pernyataan Tillman et al.,(1991) yang menyatakan bahwa kecernaan protein tergantung pada kandungan protein di dalam ransum. Pada umumnya ransum yang mengandung protein rendah mempunyai kecernaan yang rendah pula dan sebaliknya. Tinggi rendahnya kecernaan protein tergantung pada kandungan protein bahan pakan dan banyaknya protein yang masuk dalam saluran pencernaan.

\section{Kecernaan Energi}

Energi sangat diperlukan untuk proses metabolisme, aktivitas fisik, pertumbuhan dan reproduksi (NRC,1993). Kecernaan energi adalah jumlah energi pada pakan yang diserap oleh tubuh ikan dan tidak dikeluarkan melalui feses.

Berdasarkan nilai kecernaan energi pada tabel 2, pada perhitungan Analysis of Varian (ANOVA) menunjukkan tidak terdapat perbedaan yang nyata antar perlakuan $(p>0,05)$. Hal ini diduga karena pada pakan perlakuan memiliki kandungan energi yang hampir sama sehingga menyebabkan kandungan nilai kecernaan pada setiap perlakuan tidak terdapat perbedaan nilai kecernaan.

Hal tersebut sesuai dengan pernyataan (Badan Standar Nasional, 2009) yang menyatakan bahwa apabila semua perlakuan yang diberikan dengan nilai yang hampir sama memberikan sama pengaruhnya terhadap kecernaan energi ikan dan dikarenakan pakan yang dikonsumsi antar perlakuan relatif samadan memiliki kandungan energi yang sudah memenuhi kebutuhan energi untuk ikan yang berkisar antara $2409-2711 \mathrm{kkal} / \mathrm{kg}$.

\section{Kualitas Air}

Kualitas air pada penelitian ini merupakan data pendukung yang sangat penting karena air sebagai media untuk hidup yang dapat berpengaruh terhadap proses pertumbuhan dan kelangsungan hidup ikan. Suhu air pemeliharaan ikan lele berkisar antara $28-30^{\circ} \mathrm{C}$. Hal ini sesuai dengan pendapat Sutomo (2000) bahwa suhu optimal untuk ikan lele berkisar antara $26-30^{\circ} \mathrm{C}$. Kadar oksigen terlarut (DO) pada media pemeliharaan ikan lele adalah $4 \mathrm{mg} / \mathrm{l}$. Menurut Djarijah

Diterima/submitted:24 Februari 2017 Disetujui/accepted:28 Maret 2017 
(1995) kandungan oksigen terlarut mempengaruhi nafsu makan ikan. Semakin rendah kandungan oksigen terlarut dalam air, maka nafsu makan ikan berkurang.

Derajat keasaman $(\mathrm{pH})$ selama pemeliharaan ikan lele berkisar antara 7,58,0. Hal ini sesuai dengan pendapat Himawan (2008) bahwa Keasaman atau $\mathrm{pH}$ yang baik bagi lele adalah $6,5-9, \mathrm{pH}$ yang kurang dari 5 sangat buruk bagi lele karena bisa menyebabkan penggumpalan lendir pada insang, sedangkan $\mathrm{pH} 9$ ke atas akan menyebabkan berkurangnya nafsu makan lele.

\section{KESIMPULAN DAN SARAN Kesimpulan}

Berdasarkan penelitian yang berjudul Potensi penambahan Azolla sp. Terhadap Nilai Kecernaan Protein dan Kecernaan Energi pada Ikan Lele (Clarias sp.) Menggunakan Teknik Pembedahan dapat diambil kesimpulan bahwa dengan pemberian pakan formulasi yang ditambahkan dengan azolla meningkatkan kecernaan protein. Kecernaan meningkat pada perlakuan P3 dengan penambahan azolla sebanyak 15\% karena hasil perhitungan statistik mendapatkan hasil yang berbeda nyata $(\mathrm{P}<0,05)$ yang artinya memberikan pengaruh terhadap kecernaan protein ikan lele. Sedangkan pemberian pakan formulasi yang ditambahkan dengan azolla menunjukkan hasil statistik tidak berbeda nyata terhadap kecernaan energi $(\mathrm{P}>0,05)$ yang artinya tidak memberikan pengaruh terhadap kecernaan energi.

\section{Saran}

Berdasarkan penelitian yang dilakukan perlu digunakan penambahan Azolla dengan jumlah masing-masing perlakuan lebih tinggi sehingga diharapkan dapat lebih meningkatkan kecernaan protein dan kecernaan energi ikan lele (Clarias sp.).

\section{DAFTAR PUSTAKA}

Affandi, R., D.S. Sjafei, M.F. Rahardjo, dan Sulistiono. 1992. Ikhtiologi. Suatu Pedoman Kerja Labora- torium. Departemen Pendidikan dan Kebudayaan. Direktorat Jenderal Pendidikan Tinggi. Pusat Antar Universitas Ilmu Hayat. Institut Pertanian Bogor, Bogor.

Afrianto, E. dan E. Liviawati 2005. Pakan Ikan. Penerbit Kanisius. Yogyakarta.

Badan Standardisasi Nasional. 2009. Pakan Buatan untuk Ikan Gurami (Osphronemus gouramy, Lac.). https://defishery.files.wordpress.co $\mathrm{m} / 20$ 09/11/sni-pakan-gurami.pdf. Diakses tanggal 14 Januari 2016. Hal 2.

Cecep, H., A. Fanindi, S. Sopiyana, dan Komarudin. 2011. Peluang Pemanfaatan Tepung Azolla Sebagai Bahan Pakan Sumber Protein untuk Ternak Ayam. Seminar Nasional Teknologi Peternakan dan Veteriner 2011. Balai Penelitian Ternak.

Departemen Kelautan dan Perikanan.2003. Perikanan Budidaya Indonesia. Jakarta.

Djarijah, A. S. 1995. Pakan Ikan Alami. Kanisius. Yogyakarta. Hal 16, 22.

Handayani, H. 2006. Pemanfaatan Tepung Azolla sebagai Penyusun Pakan Ikan terhadap Pertumbuhan dan Daya Cerna Ikan Nila Gift (Oreochromis sp.). Jurnal aquaculture, Vol 1, No 2. September, 2006 : 162-170.

Himawan. 2008. Budidaya Lele Sangkuriang.

http://IndonesiaIndonesia.com/f/18 253-budidaya-lele-sangkuriangclarias-sp/. 11.30. 23 Juni 2012.

Kusriningrum, R.S. 2008. Perancangan Percobaan. Airlangga University Press. Surabaya.

Murtidjo, B. A. 2001. Pedoman Meramu Pakan Ikan. Kanisius. Yogyakarta. Hal 48.

NRC. 1993. Nutrient Requirements of Fish. National Academy Press. Washington D.C. USA.

Ranjhan, S. K., 1997. Animal Nutrition and Feeding Practice In India. 
Vikan Pub. House PVT Ltd. New Delhi.

Soetomo, M. 2000. Teknik Budidaya Ikan Lele dumbo. Sinar Baru Algensindo. Bandung. Hal 5-90.

Tillman, A.D., H. Hartadi, S. Reksohadiprojo, S. Prawirokusumo. dan S. Lebdosoekojo. 1998. Ilmu Makanan Ternak Dasar. Edisi Keenam. Gadjah Mada University Press. Yogyakarta.

Utama, S., I. Estiningdriati, V. D. Yunianto dan W. Murningsih. 2006. Pengaruh Penambahan Aras Mineral pada Fermentasi Sorghum dengan Ragi Tempe Terhadap Kecernaan Zat Pakan pada Ayam Petelur. Ejournal-UMM. Malang. 